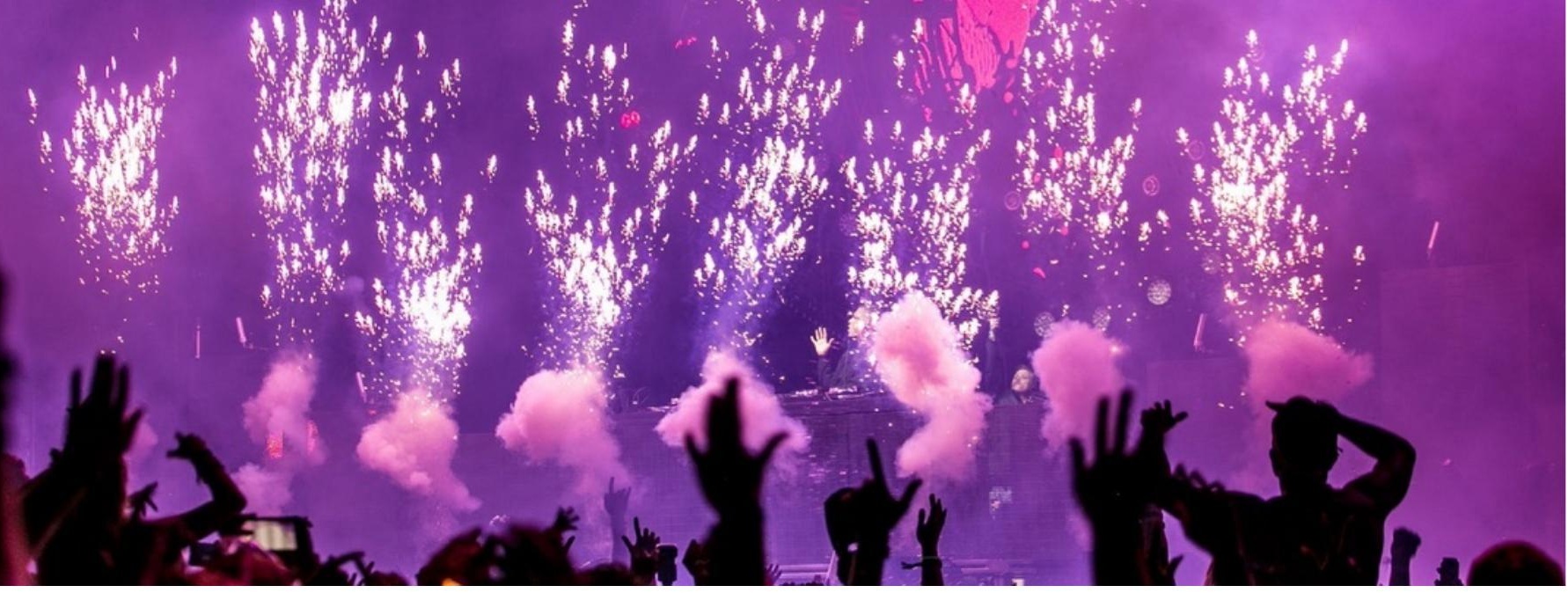

\title{
What is going on with the classic audience? - Klassik ab 70?
}

\author{
Authors: $\quad$ Leander Hotaki \\ Submitted: $\quad$ 7. March 2019 \\ Published: $\quad$ 11. March 2019 \\ Volume: 6 \\ Issue: $\quad 3$ \\ Languages: German \\ Keywords: $\quad$ Music, Columm, Freiburg, Classic music, Doping \\ Categories: $\quad$ Performing Arts, Music \\ DOI: $\quad$ 10.17160/josha.6.3.545
}

Abstract:

Leander Hotaki is since 2010 the director of the German program called "Albert Konzerte" which is a program in charge of making possible to bring the greatest artist of the World to Freiburg and to make the most wonderful concerts in the south-west of Germany. In fact, he also promotes the work of the best students in the field of dramaturge or music in many universities in Germany and writes columns about different topics around music and musicians. This time he writes about the very wrong idea many people has about the audience of classic music. They think the classic is losing his audience in the future.

\section{JOSHA Jounalosesereas Humanities and Arts




\section{Klassik ab 70?}

\section{Dr. Leander Hotaki}

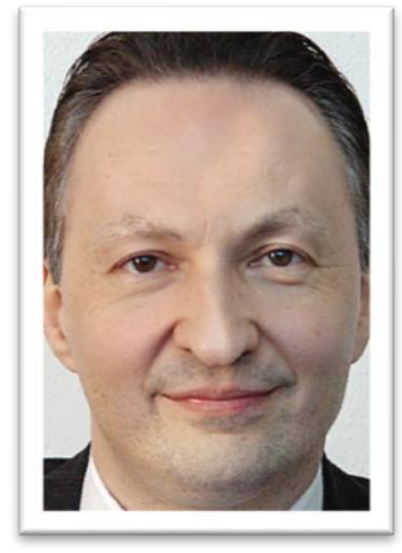

$\mathrm{U}_{\mathrm{m}}$ die klassische Musik kreisen viele Mythen. So hält sich in Deutschland hartnäckig die Meinung, dass das Publikum für klassische Konzerte in absehbarer Zeit aussterbe, und bereits jetzt nur noch ein „Silbersee“ in den Konzertsälen sitze. So ein Unsinn, möchte man ausrufen, denn: sachlich falsch. Niemals haben so viele Menschen in Deutschland klassische Musik live erlebt wie heute.

Zwar geht vielerorts die Zahl der Abonnenten von Klassik-Konzertreihen deutlich bis drastisch zurück, aber viele Konzertreihen, die medial und inhaltlich für die Zukunft gut aufgestellt sind, haben weiterhin ihr gutes Auskommen. Ganz zu schweigen von den Hundertschaften klassischer Musikfestivals in Deutschland, die in den letzten
Jahrzehnten und Jahren gegründet wurden: Sie verzeichnen vielerorts phantastische Auslastungen und haben zudem viel junges Publikum gewonnen. Denn Festivals bieten die Möglichkeit, freie Terminwahl in der Urlaubszeit mit Event-Feeling zu verbinden.

Fazit: Zum einen endet die Klassik Zuspruch vom „Silbersee“, der äußerst munter und aktiv ist, zumal das Klassik-Publikum schon immer im Durchschnitt älter war; zum anderen sind viele junge Menschen bei Klassik-Konzerterlebnissen mit von der Partie. Mehr denn je in der Geschichte. Und jenseits des Konzerts natürlich auch über Download, Streaming, Spotify usw. Vielleicht hat sich hier auch das Konsumverhalten gewandelt: heute Herbert Grönemeyer, morgen Klassik, übermorgen Techno?!

Damit die Klassik auch in 30 Jahren lebendiger Teil unserer Gesellschaft ist, sind wir alle gefordert: in der Familie, indem wir unsere Kinder an Musik heranführen und vielleicht selbst musizieren; in der Schule, indem der Musikunterricht wieder als wichtig für die Bildung junger Menschen erkannt wird. Klassik ab 70? Nein, für Menschen jeder Altersklasse, die neugierig sind!

\section{Dr. Leander Hotaki}

